\title{
PHENOTYPIC ASSOCIATION BETWEEN RESIDUAL FEED INTAKE AND CARCASS TRAITS OF YOUNG NELORE BULLS
}

\author{
Bruna Suellen Borges Resende BEZERRA ${ }^{1}$ (i), Mariana Mundim Alves GOMES ${ }^{1}$ (D), \\ Danilo Rodrigues BOAVENTURA ${ }^{1}$ (D) , Aline Maria Soares FERREIRA ${ }^{1}$ (D), \\ Egleu Diomedes Marinho MENDES ${ }^{2}$ (D), Carina Ubirajara de FARIA ${ }^{1}$ iD
}

${ }^{1}$ Faculty of Veterinary Medicine, Federal University of Uberlândia, , Uberlândia, Minas Gerais, Brazil.

2 Department of Animal Science, Texas A\&M University, College Station, Texas, United States.

Corresponding author:

Mariana Mundim Alvez Gomes

Email: mmundim95@yahoo.com.br

How to cite: BEZERRA, B.S.B.R., et al. Phenotypic association between residual feed intake and carcass traits of young Nelore bulls. Bioscience Journal. 2021, 37, e37081. https://doi.org/10.14393/BJ-v37n0a2021-48077

\begin{abstract}
The purpose of this study was to estimate the phenotypic associations between residual food intake (RFI) and carcass traits, evaluated by ultrasonography, of young Nellore bulls. Information about 53 young Nelore bulls, pure origin (PO), participants in the Individual Performance Test of Nelore Bulls, carried out at the Capim Branco experimental farm of the Federal University of Uberlândia (UFU) were used for this purpose. It was evaluated the characteristics of residual feed intake (RFI), rib eye area (REA), marbling (MAR) and fat thickness (FT). In order to estimate the Spearman and Pearson correlation coefficients, the SAS program was used. Regarding the influence of the RFI classes (low RFI, medium RFI and high RFI) on carcass traits, an out analysis of variance was carried out using the least squares method. It was verified that there was no phenotypic association between RFI and the characteristics of REA and MAR, but the relation between FT and the phenotypic association revealed a medium magnitude. However, when evaluating the RFI classes, it was observed that there were no significant differences of the RFI classes with the carcass traits (REA, FT and MAR). It is recommended that new studies are carried out to verify if the selection for RFI does not result in damages to the finishing of carcass in Nelore cattle.
\end{abstract}

Keywords: Carcass Yield. Fat Thickness. Feed Efficiency.

\section{Introduction}

Brazil has the largest commercial cattle herd in the world, about 209 million head (Gomes et al. 2017), the zebu ones stand out for the economic importance, reaching $80 \%$ of the national herd (ABCZ 2007). In this scenario, despite the fact that the genetic improvement led to achieve better results, the economic agents still recognize the low productivity indexes of beef cattle (Faria et al. 2007).Considering that food represents the highest cost of a production system (Almeida 2005), ranging from $70 \%$ to $90 \%$ of total costs, depending on the system and stage of production (Corvino 2010), the selection of more efficient animals for the use of nutrients (inputs) can lead to a great advance of beef cattle, by reducing production costs, without affecting the zootechnical indexes, guaranteeing the sustainability of the activity.

One of the tools to improve the productivity indexes of herds, for the various characteristics of economic interests, is the selection of the best animals, with the purpose of promoting the genetic improvement, and consequently the increase of productivity. In Brazil, the expansion of genetic improvement programs applied to beef cattle is clear, however, the selection has been mainly based on 
characteristics related to growth. According to Chaves (2013), these characteristics are known as outputs, due to the ease of obtaining field data and the rapid response to selection. In this context, the Residual Feed Intake (RFI) measurement is of great importance since it allows the identification of genetically efficient animals, with a lower food intake, promoting the increase of productivity at the same time in which the cost of production is reduced (Gomes et al. 2012).

In Brazil, breeding programs already use EPDs (expected progeny difference) for RFI, which facilitates the selection of the most efficient animals. Even so, it is necessary to evaluate the genetic and environmental factors that influence food efficiency, as well as verify their association with productivity characteristics such as growth, reproduction and carcass quality.

Among the measures related to feed efficiency, RFI is the most used in beef cattle. RFI is calculated by the difference in observed dry matter intake (DMlo) during the test and the expected dry matter intake (DMle) based on the animal's live weight and weight gain (Gomes et al. 2012). Thus, more efficient animals are those that consume less than expected, and less efficient animals are those that consume more than expected, considering a specific gain of weight.

One of the great advantages of RFI is that the heritability estimate varies from medium to high, indicating that selection for such trait will bring genetic progress (Ferreira et al. 2012). Some international researches were carried out to identify the most efficient genotypes by measuring the residual feed intake, mainly for European bovine breeds (Liu et al. 2000; Basarab et al. 2003; Wang et al. 2006; Moore et al. 2009), and recently the Japanese Wagyu breed (Mcgee et al. 2013). However, few studies have been done with zebu animals, highlighting those of Arthur et al. (2005), Gomes (2009), Santana (2009) and Grion (2012), carried out in Brazil.

The phenotypic associations between RFI and carcass traits evaluated by ultrasound in beef cattle are indispensable in the selection programs, since these parameters constitute basic elements that guide the genetic improvement of cattle (Oliveira et al. 1993).

Thus, this study aimed to estimate the phenotypic associations between the residual feed intake and the quantitative carcass traits of young bulls of the Nelore breed, evaluated by ultrasonography.

\section{Material and Methods}

To carry out the present study, information of 53 young Nelore bulls, pure of origin (PO), participants of the Individual Performance Test of Nelore Bulls in the Capim Branco experimental farm of the Federal University of Uberlândia were collected from June to August of 2014. The animals are from all over Brazil, with an average age of 22 months. The characteristics of residual feed intake (RFI), rib eye area (REA), fat thickness (FT) and marbling (MAR) were evaluated. The carcass measurements were evaluated before the beginning of the experiment (pasture feeding regime, $\mathrm{P}$ ) and at the end of the experiment (feeding confinement regime, $C$ ). It was not possible to measure MAR at the beginning of the experiment due to age (mean of 18 months) and pasture management.

To measure the carcass traits, ultrasound images were collected using an ALOKA 500V instrument with a $17.2 \mathrm{~cm}$ linear probe of $3.5 \mathrm{MHz}$ and an acoustic coupler in conjunction with an image capture system (Blackbox, Bionitrics, Inc., Ames, IA, USA). These images were interpreted by the laboratory responsible for data quality assurance (Aval Serviços Tecnológicos $S / S$ ).

The animals were kept in confinement. The site occupies an area of 1,680 $\mathrm{m}^{2}$ (42 $\left.\mathrm{m} \times 40 \mathrm{~m}\right)$, divided into two pens, with a central drinking fountain of 2,600 liters. Each pen contains four electronic feeders (with coverage) of the GrowSafe ${ }^{\circledast}$ System. The feed efficiency test lasted 91 days, with 21 days for adaptation and 70 days for evaluation. The animals were in a contemporary group, with an age range of 60 days and average age of 22 months at the end of the experiment.

The animals were weighed at the beginning and end of the test and, also, at 14-day intervals without fasting. The diet was given ad libitum in the form of a single total ration, aiming at average daily gains of 1.2 $\mathrm{kg} / \mathrm{animal} / \mathrm{day}$. The feed formulation started with $80 \%$ of voluminous (maize silage) and $20 \%$ of concentrate (milled corn, soybean meal, urea, and mineral nucleus) during the adaptation period, after which the experiment was effectively started to $70 \%$ voluminous and $30 \%$ concentrated, for about 11 days. From the $12^{\text {th }}$ day of experiment until the end, the diet was $60 \%$ of voluminous and $40 \%$ of concentrate, following the 
recommendations of the NRC (1996) for the expected gains. Feeding was done three times a day, adjusted daily to ensure leftovers around $10 \%$ of the feed.

Weekly analyzes of the percentage of dry matter (\% DM) of the diet provided, as well as of the leftovers and the corn silage, were carried out to verify if there was variation in the food supplied throughout the day. At 14-day intervals, neutral detergent fiber (NDF) bromatological analyzes were performed; acid detergent fiber (ADF), in order to determine if the formulated diet was the same as that provided.

For the evaluation of feed efficiency, the information of RFI was used. As described by Gomes et al. (2012), the RFI is calculated as the difference of dry matter intake observed (DMlo) during the test and the dry matter intake expected (DMle) based on the live weight of the animal and weight gain. The live weight of the animal is defined as Metabolic mid-weight (METABOLIC MIDWT) and was calculated as follows:

$$
\text { Metabolic MIDWT }=\left(\frac{I W T+F W T}{2}\right)^{0,75}
$$

Where, IWT is the initial weight and FWT is the final weight at the test of feed efficiency. The data of dry matter intake (DMI), average daily gain (ADG) and Metabolic mid-weight (METABOLIC MIDWT) of all test animals were used to predict the coefficients $(\beta)$ of the multiple linear regression equation, as shown:

$$
D M I=\beta 0+(\beta 1 * A D G)+(\beta 2 * \text { Metabolic MIDWT })
$$

Once the equation was established, the expected dry matter intake (DMle) for each animal was calculate. The RFI calculation (in kilos) is given by equation suggested by Koch et al. (1963):

$$
R F I=D M I o-D M I e
$$

In order to build the descriptive and statistical analyzes it was used the program Statistical Analysis System (SAS 2004). It was also used the Microsoft Excel package for data file preparation and graphing. The estimation of Spearman and Pearson correlation coefficients between the residual feed intake and carcass traits were based on the SAS. The descriptive statistics of the evaluated characteristics are presented in Table 1.

Table 1. Descriptive statistics of residual feed intake (RFI), rib eye area (REA), fat thickness (FT) and marbling (MAR), measured at confinement.

\begin{tabular}{ccccccc}
\hline Variable & $\mathrm{N}$ & Mean & SD & CV (\%) & Minimum & Maximum \\
\hline RFI (Kg DM/day) & 53 & 0.00 & 1.30 & 0 & -2.91 & 5.99 \\
REA $\left(\mathrm{cm}^{2}\right)$ & 53 & 81.43 & 6.58 & 8.08 & 68.65 & 100.26 \\
FY $(\mathrm{mm})$ & 53 & 6.31 & 1.37 & 21.71 & 3.66 & 10.55 \\
MAR(\%) & 46 & 2.67 & 0.53 & 19.85 & 1.91 & 4.38 \\
\hline
\end{tabular}

SD: Standard Deviation; CV: Coefficient of Variation.

The RFI characteristic showed genetic variability with normal distribution. In this way, the RFI classes were elaborated, considering 17 animals with low RFI (32.5\%), 17 animals with medium RFI (32.5\%) and 19 animals with high RFI (35\%). To verify the influence of the classes of residual feed intake (low RFI, medium $\mathrm{RFI}$ and high RFI) on carcass traits, analyzes of variance (ANOVA) were performed using the least squares method using the GLM procedure (General Linear Model), in which the statistical model is presented below:

$$
y_{i j}=\mu+R F I_{i}+e_{i j}
$$

Where $y_{i j}$ is the vector of observations (phenotypic carcass traits); = overall mean of the

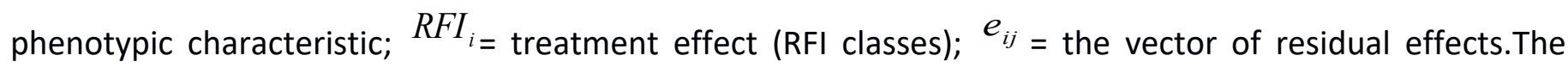
comparison of means was performed by the Tukey test, being considered the statistical difference when $\mathrm{P} \leq$ 0,05 .

\section{Results and Discussion}

Among the 53 animals analyzed, 24 (45.28\%) had negative RFI and 29 (54.72\%) presented positive RFI. The best result was $-2.909 \mathrm{~kg} \mathrm{DM}$, that is, the animal ingested $2.909 \mathrm{~kg}$ DM/Day less than expected, therefore, this animal was more efficient in the contemporary group. The worst result was $5.332 \mathrm{~kg} \mathrm{DM}$, that is, the animal ingested $5.332 \mathrm{~kg}$ of DM/Day more than expected. This animal with lower RFI ingested $8.4 \mathrm{~kg}$ 
DM/day, obtained a final weight of $544 \mathrm{~kg}$ and an ADG of $1.51 \mathrm{~kg} /$ day. The animal with the highest RFI consumed $17.5 \mathrm{~kg} \mathrm{DM} /$ day, its final weight was $605 \mathrm{~kg}$ and the ADG was $1.76 \mathrm{~kg} / \mathrm{day}$.

In order not to have RFI interference in the growth and adult size of the herd the RFI was adjusted for Metabolic mid-weight (METABOLIC MIDWT), it becomes independent of this characteristic (Chaves 2013).

The Table 2 shows the phenotypic associations between RFI, and the carcass traits measured in young Nelore bulls, recreated under pasture, and then finished in confinement. It was observed that, practically, there is no association between RFI and the rib eye area (REA), measured the beginning (grazing regime) and at the end of the experiment (confinement regime). Thus, it can be inferred that when selecting for RFI there will be no interference in REA. Chaves (2013) conducted a research with Nellore animals and reports that more efficient animals for RFI result in carcasses with higher REA, thus altering the body composition with the increase of the protein content of the gain.

Regarding the fat thickness (FT), it was verified that the estimates of phenotypic correlation with RFI were of medium magnitude, indicating that the increase in RFI can be explained in part (18.5\% for FTc and $16.8 \%$ for FTp) by the increase of fat deposition. These results corroborate with Farjalla (2009) that related the need to study the influence of FT in the measurement of RFI, since animals in the final stage tend to consume more food.

The results presented on Table 2 may suggest that selection for RFI may negatively influence the FT, in agreement with Richardson et al. (2001) and Robinson et al. (2004). Nascimento (2011) and Santana et. al. (2014) also to found a positive association between RFI and fat thickness. Basarab et al. (2003) detected a positive association for RFI and body fat. Herd et al. (2004) verified a percentage of RFI contribution of $5 \%$ difference in body composition. A proposal to reduce the negative effect of RFI in FT is to perform the correction of RFI to FT, however, Corvino (2010) stated that there is no interference of RFI in the carcass traits. Chaves (2013) concluded that low RFI animals present increased lean tissue and reduced fat content, however, there was no reduction in subcutaneous fat thickness.

Table 2. Pearson correlation coefficient (above diagonal) between residual feed intake (RFI), dry matter intake (DMI), rib eye area in pasture and confinement (REAp, REAC), fat thickness (FTp and FTc) and marbling (MARc) for young bulls of the Nelore breed. Below the diagonal are represented the significance of the correlations.

\begin{tabular}{|c|c|c|c|c|c|c|c|}
\hline & RFI & $\mathrm{DMI}$ & REAc & $\mathrm{FT}_{\mathrm{C}}$ & $\mathrm{MAR}_{\mathrm{C}}$ & REAP & $\mathrm{FT}_{\mathrm{p}}$ \\
\hline RFI & 1 & 0.87 & -0.12 & 0.43 & 0.16 & -0.19 & 0.41 \\
\hline DMI & $<0.0001$ & 1 & -0.02 & 0.56 & 0.16 & -0.02 & 0.44 \\
\hline REAc & 0.38 & 0.90 & 1 & -0.14 & -0.17 & 0.75 & -0.25 \\
\hline $\mathrm{FT}_{\mathrm{C}}$ & 0.001 & $<0.0001$ & 0.32 & 1 & 0.01 & -0.28 & 0.48 \\
\hline $\mathrm{MAR}_{\mathrm{C}}$ & 0.28 & 0.29 & 0.25 & 0.97 & 1 & -0.07 & -0.07 \\
\hline $\mathrm{REA}_{\mathrm{P}}$ & 0.18 & 0.87 & $<0.0001$ & 0.04 & 0.63 & 1 & -0.27 \\
\hline $\mathrm{FT}_{\mathrm{p}}$ & 0.002 & 0.001 & 0.08 & 0.0003 & 0.62 & 0.05 & 1 \\
\hline
\end{tabular}

Marbling had practically no phenotypic association with RFI. However, as expected, RFI is highly associated with DMI. When estimating the phenotypic correlations of the DMI with the fat thickness (FTC and FTp), it was verified that they were higher than those estimated with the RFI. These results show that the RFI, when calculated based on the metabolic weight and weight gain of the animals belonging to the same contemporary group, allows the correction of possible discrepancies that could occur when considering only DMI and ADG, as in the feed conversion. It can also be observed that there is no association between the DMI and the rib eye area (REAc, REAp).

It should be noted that the FT measurements obtained in the same animals, however, evaluated in different feeding regimes (pasture and confinement) and with a 100-day interval between the two measurements, showed a medium magnitude phenotypic association. This result shows that the age of the animals as well as the food supply may influence the gene expression for this trait and that animals selected in an environmental (limiting) condition may present different phenotypic responses in a favorable breeding condition. However, for REA it is observed that the phenotypic correlation between the measures at 
different times (pasture and confinement) was of high magnitude, indicating that the measurement taken earlier may be effective in the selection of animals for such characteristic indicating the yield of carcass.

Similar results were observed for Spearman correlations between RFI and carcass traits (Table 3). It should be noted that although the animals belong to the same contemporary group, differences in the stages of growth of the animals can occur, due to the existence of later animals and other earlier animals, presenting different growth curves, which may explain the correlation of 0.75 between REAc and REAp.

Table 3. Spearman correlation coefficient (above diagonal) between residual feed intake (RFI), dry matter intake (DMI), rib eye area (REAp, REAc), fat thickness (FTp and FTc) and marbling (MARc) for young bulls of the Nelore breed. Below the diagonal are represented the significance of the correlations.

\begin{tabular}{cccccccc}
\hline & $\mathrm{RFI}$ & $\mathrm{DMI}$ & $\mathrm{REA}$ & $\mathrm{FT}_{C}$ & $\mathrm{MAR}_{C}$ & $\mathrm{REA}$ & $\mathrm{FT}_{\mathrm{P}}$ \\
\hline $\mathrm{RFI}$ & 1 & 0.78 & -0.17 & 0.32 & 0.18 & -0.20 & 0.31 \\
$\mathrm{DMI}$ & $<0.0001$ & 1 & -0.08 & 0.48 & 0.21 & -0.04 & 0.38 \\
$\mathrm{REA}_{C}$ & 0.22 & 0.58 & 1 & -0.20 & -0.25 & 0.76 & -0.30 \\
$\mathrm{FT}_{C}$ & 0.02 & 0.0003 & 0.14 & 1 & 0.03 & -0.28 & 0.47 \\
$\mathrm{MAR}_{C}$ & 0.24 & 0.17 & 0.09 & 0.86 & 1 & -0.16 & -0.01 \\
$\mathrm{REA}_{\mathrm{P}}$ & 0.15 & 0.80 & $<0.0001$ & 0.04 & 0.29 & 1 & -0.31 \\
$\mathrm{FT}_{\mathrm{P}}$ & 0.02 & 0.01 & 0.03 & 0.0003 & 0.93 & 0.03 & 1 \\
\hline
\end{tabular}

It is known that the growth curve of the tissues of the animals is allometric, that is, it grows disproportionately (Sakamoto 2012). Thus, from conception to birth there is a great bone growth, after birth until puberty rapidly develops muscle tissue and puberty until maturity, occurs large deposition of adipose tissue. As the animal gets older the food efficiency is reduced, due to the greater deposition of fat in relation to the deposition of protein, because the fat requires more energy for its deposition.

Table 4 shows the phenotypic averages of carcass traits (REAp, FTp, REAc, FTc and MARc) measured in animals with low RFI, medium RFI and high RFI values. There was no significant influence of the RFI class for all the characteristics evaluated ( $p>0.05$ ). These results corroborate with those found by Sainz et al. (2006) who also did not observe significant differences of high RFI and low RFI for the characteristics of longissimus muscle area, marbling and fat covering on carcass of Angus/Hereford heifers.

Table 4. Phenotypic parameters of carcass traits of Nelore young bulls reared under pasture (REAp and FTp) and later in confinement termination phase (REAc,FTc and MARc) classified as low, medium and high residual feed intake (RFI).

\begin{tabular}{|c|c|c|c|c|}
\hline \multirow{2}{*}{ Parameters } & \multicolumn{3}{|c|}{$\mathrm{RFI}$} & \multirow{2}{*}{$P$} \\
\hline & Low & Medium & High & \\
\hline $\mathrm{FT}_{\mathrm{P}}(\mathrm{mm})$ & 2.07 & 2.32 & 2.48 & 0.0571 \\
\hline $\mathrm{FT}_{\mathrm{C}}(\mathrm{mm})$ & 5.69 & 6.46 & 6.73 & 0.0628 \\
\hline $\operatorname{REA} A_{P}\left(\mathrm{~cm}^{2}\right)$ & 61.23 & 60.26 & 59.05 & 0.5597 \\
\hline $\operatorname{REA}\left(\mathrm{cm}^{2}\right)$ & 82.85 & 79.83 & 81.59 & 0.4120 \\
\hline $\operatorname{MAR}_{C}(\%)$ & 2.25 & 2.39 & 2.31 & 0.5808 \\
\hline
\end{tabular}

$P$ value greater than $5 \%(p>0.05)$ is not significant.

Farjalla (2009) did not identify significant differences of high, medium and low RFI for the characteristics of longissimus muscle area, marbling and subcutaneous fat of Nelore steers of approximately 18 months of age. Chaves (2013) conducted a Nelore survey, with castrated animals of 20 months average age and did not obtain an efficient and ineffective relationship between RFI classes and REA but claims that animals with inefficient RFI present greater deposition of subcutaneous fat. Ahola et al. (2011) reported no significant interference of the RFI groups on fat thickness. Contrary results were observed by Richardson et al. (2001) who verified that animals with negative RFI had lower fat thickness when compared to animals with positive RFI.

The dispersion of the animals based on the information of the RFI in relation to the FT is presented in Figure 1. It is observed that the animals belonging to the quadrant I are those of interest in the selection 
process, since they present lower RFI and higher FT. Among the 53 animals evaluated in this study, $22.6 \%$ are in quadrant $\mathrm{I}$.

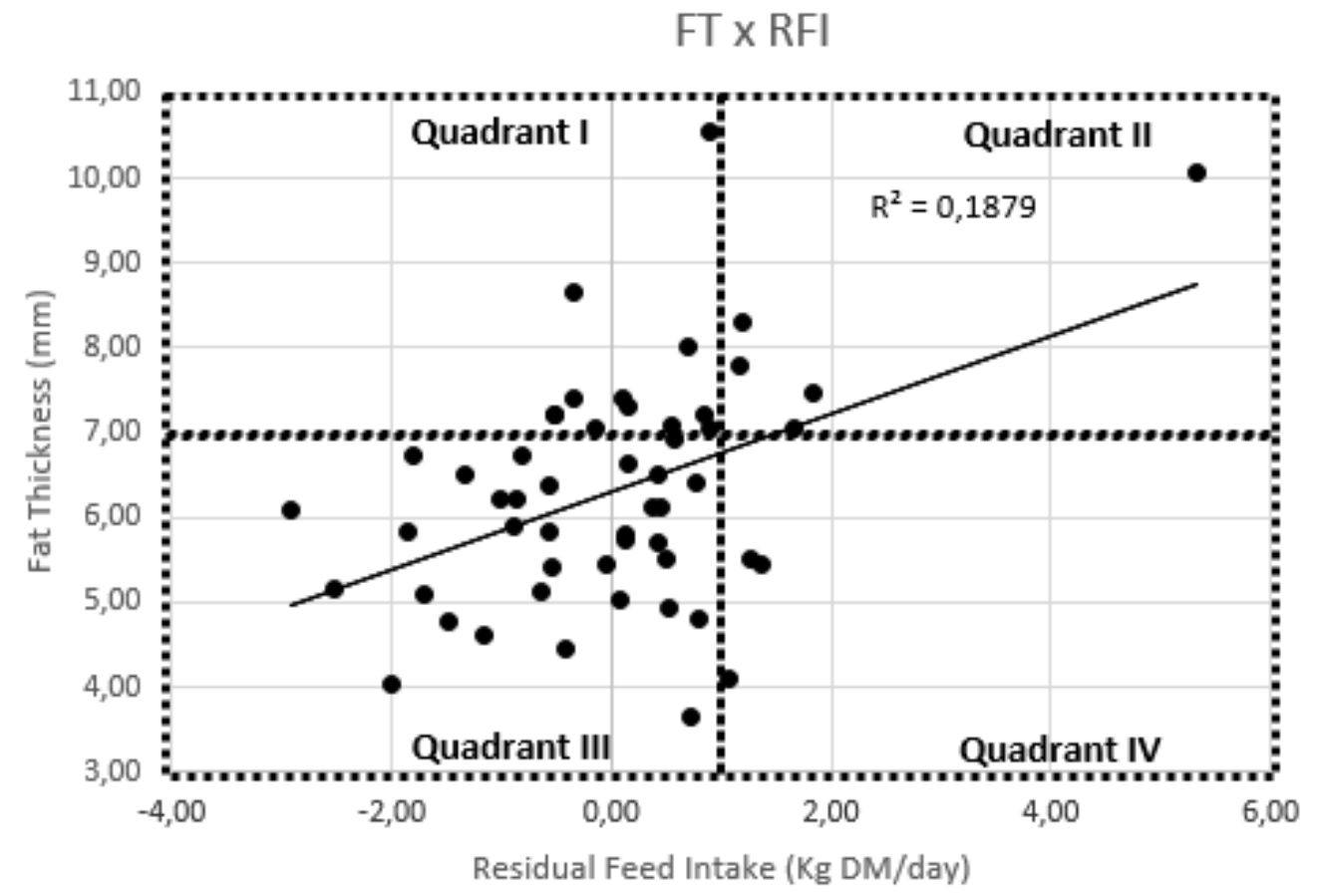

Figure 1. Evaluation of the data dispersion considering the fat thickness (FT) and residual feed intake (RFI) of young Nelore bulls.

\section{Conclusions}

The RFI does not influence the carcass traits, except for the FT that presented a moderate and positive correlation in Nelore bulls.

Authors' Contributions: BEZERRA, B.S.B.R.: conception and design, analysis and interpretation of data, drafting the article; GOMES, M.M.A.: analysis and interpretation of data, drafting the article; BOAVENTURA, D.R. analysis and interpretation of data, drafting the article; FERREIRA, A.M.S.: analysis and interpretation of data, drafting the article; MENDES, E.D.M.: acquisition of data, analysis and interpretation of data; FARIA, C.U.: conception and design, acquisition of data, analysis and interpretation of data. All authors have read and approved the final version of the manuscript.

Conflicts of Interest: The authors declare no conflicts of interest.

Ethics Approval: Approved by Committee for Ethics in the use of Animals of the Federal University of Uberlândia. Number: A015/21.

Acknowledgments: Not applicable.

\section{References}

ABCZ - Associação Brasileira de Criadores de Zebu. Regulamento do serviço de registro genealógico das raças zebuínas. Uberaba: Associação Brasileira de Criadores de Zebu, 2007.

AHOLA, J.K., et al. Relationship between residual feed intake and end product palatability in longissimus steaks from steers sired by Angus bulls divergent for intramuscular fat expected progeny difference. The Professional Animal Scientist. 2011, 27(2), 109-115.

https://doi.org/10.15232/S1080-7446(15)30456-3

ALMEIDA, R. Consumo e eficiência alimentar de bovinos em crescimento. Tese (Doutorado em Agronomia). Piracicaba: Universidade de São Paulo, 2005. https://doi.org/10.11606/T.11.2005.tde-09112005-150314

ARTHUR, P.F., et al. Maternal productivity of Angus cows divergently selected for post weaning residual feed intake. Australian Journal of Experimental Agriculture. 2005, 45, 985-993. https://doi.org/10.1071/EA05052

BASARAB, J.A., et al. Residual feed intake and body composition in young growing cattle. Canadian journal of animal Science. 2003, 83(2), 189204. https://doi.org/10.4141/A02-065

CHAVES, A.S. Relações entre eficiência alimentar e característica de carcaça, qualidade de carne, batimentos cardíacos e consumo de oxigênio em bovinos. Tese (Doutorado em Ciência animal e pastagens). Piracicaba: Universidade de São Paulo, 2013. Available from:

http://www.teses.usp.br/teses/disponiveis/11/11139/tde-05112013-162453/pt-br.php 
CORVINO, T.L.S. Caracterização do consumo alimentar residual e relações com desempenho e características de carcaça de bovinos nelore. Dissertação (Mestrado em Medicina Veterinária). Botucatu: Universidade Estadual Paulista, Faculdade de Medicina Veterinária e Zootecnia, 2010. Available from: http://www.dominiopublico.gov.br/pesquisa/DetalheObraForm.do?select action=\&co obra=168566

FARIA, C.U., et al. Bayesian inference in the quantitative genetic study of growth traits in Nelore cattle (Bos indicus). Genetics and Molecular Biology. 2007, 30(3), 545-551. https://doi.org/10.1590/S1415-47572007000400007

FARJALLA, Y.B. Desempenho, características de carcaça e qualidade de carne de bovinos Nelore estratificados pela eficiência através do consumo alimentar residual. Dissertação (Mestrado em Ciência animal e pastagens). Piracicaba, Universidade de São Paulo, 2009. Available from: http://www.teses.usp.br/teses/disponiveis/11/11139/tde-26022010-082854/pt-br.php

FERREIRA, F.O.B. and SANDOVAL, G. Eficiência Alimentar em Bovinos de Corte - Importância na Seleção. Uberaba: Alta Genetics, 2012. Available from: http://www.altagenetics.com.br/novo/noticias/Ler.aspx?hID=796

GOMES, R.C. Metabolismo proteico, composição corporal, características de carcaça e qualidade de carne de novilhos Nelore (Bos indicus) em função de seu consumo alimentar residual. Tese (Doutorado em Qualidade e Produtividade Animal). Pirassununga: Universidade de São Paulo, 2009. Available from: http://www.teses.usp.br/teses/disponiveis/74/74131/tde-13042009-093046/

GOMES, R. C., et al. Ingestão de alimentos e eficiência alimentar de bovinos e ovinos de corte. Ribeirão Preto: FUNPEC Editora, 2012.

GOMES, R.C., FEIJÓ, G.L.D. and CHIARI, L. Evolução e Qualidade da Pecuária Brasileira. Campo Grande: Embrapa Gado de Corte, 2017. Available from: https://www.embrapa.br/documents/10180/21470602/EvolucaoeQualidadePecuaria.pdf/64e8985a-5c7c-b83e-ba2d$\underline{168 f f a a 762 a d}$

GRION, A.L. Parâmetros genéticos de medidas indicadoras de eficiência alimentar de bovinos de corte. Dissertação (Mestrado em Produção Animal Sustentável). Nova Odessa: Instituto de Zootecnia, 2012. Available from: http://www.iz.sp.gov.br/pdfs/1367498272.pdf

HERD, R.M., ODDY, V.W. and RICHARDSON, E.C. Biological basis for variation in residual feed intake in beef cattle.1. Review of potential mechanisms. Australian Journal of Experimental Agriculture. 2004, 44, 423-430. https://doi.org/10.1071/EA02220

KOCH, R.M., et al. Efficiency of feed use in beef cattle. Journal of Animal Science. 1963, 22, 486-494. https://doi.org/10.2527/jas1963.222486x

LIU, M.F., et al. A study in the variation of feed efficiency in station tested beef bulls. Canadian Journal of Animal Science. $2000,80,435-441$. https://doi.org/10.4141/A99-030

MCGEE, M., et al. Evaluation of Wagyu for residual feed intake: Optimizing feed efficiency, growth, and marbling in Wagyu cattle. Professional Animal Scientist. 2013, 29, 51-56. https://doi.org/10.15232/S1080-7446(15)30195-9

MOORE, S.S., MUJIBI, F.D. and SHERMAN, E.L. Molecular basis for residual feed intake in beef cattle. Journal of Animal Science. 2009, 87, 4147. https://doi.org/10.2527/jas.2008-1418

NASCIMENTO, M.L. Eficiência Alimentar e suas Associações com Lucro, Características de Carcaça e Qualidade de Carne de Bovinos Nelore. Tese (Doutorado em Ciência animal e pastagens). Piracicaba: Universidade de São Paulo, 2011. https://doi.org/10.11606/ T.11.2011.tde$\underline{24012012-094448}$

NRC - NATIONAL RESEARCH COUNCIL. Nutrient requirements of beef cattle. 7.ed. Washington: The National Academies Press, 1996. https://doi.org/10.17226/9791

OLIVEIRA, J.A., LOBO, R.B. and GONÇALVES, A.A.M. Estimativas de parâmetros genéticos e fenotípicas de pesos e ganho em peso do nascimento aos 365 dias de idade em um rebanho da raça Guzerá. Boletim de Indústria Animal. 1993, 50, 119-123.

RICHARDSON, E.C., et al. Body composition and implications for heat production of Angus steers progeny of parents selected for and against residual feed intake. Australian Journal of Experimental Agriculture. 2001, 41, 1065-1072. https://doi.org/10.1071/EA00095

ROBINSON, D.L. and ODDY, V.H. Genetics parameters for feed efficiency, fatness, muscle area, and feeding behavior of feedlot finished beef cattle. Livestock Production Science. 2004, 90, 255-270. https://doi.org/10.1016/j.livprodsci.2004.06.011

SAINZ, R., GUEDES, C.F. and GOMES, R.C. Consumo alimentar, eficiência alimentar e impactos na qualidade da carne - parte I. 2006. Available from: http://www.beefpoint.com.br/radares-tecnicos/qualidade-da-carne/consumo-alimentar-eficiencia-alimentar-e-impactos-na-qualidadeda-carne-parte-i-29807/

SAKAMOTO, L.S. Predição de rendimento de cortes cárneos e teor de gordura a partir de medidas de carcaça obtidas por ultrassonografia. Dissertação (Mestrado em Produção animal sustentável). Nova Odessa: Instituto de Zootecnia, 2012.

http://www.iz.sp.gov.br/pdfs/1332338444.pdf

SANTANA, M.H.A. Relação do consumo alimentar residual e conversão alimentar com características de carcaça, perfil metabólico e sanguíneo de touros nelore. Dissertação (Mestrado em Produção Animal). Curitiba: Universidade Federal do Paraná, 2009. Available from:

http://hdl.handle.net/1884/22348

SANTANA, M.H.A., et al. Medidas de eficiência alimentar para avaliação de bovinos de corte. Scientia Agraria Paranaensis, 2014, 13(2), 95-107. https://doi.org/10.18188/sap.v13i2.7459

SAS Institute Inc. SAS OnlineDoc ${ }^{\circledR}$ 9.1.3. Cary, NC: SAS Institute Inc, 2004.

WANG, Z., et al. Test duration for growth, feed intake, and feed efficiency in beef cattle using the GrowSafe system. Journal of Animal Science. 2006, 84, 2289-2298. https://doi.org/10.2527/jas.2005-715 
Received: 25 April 2020 | Accepted: 14 December 2020 | Published: 29 December 2021

This is an Open Access article distributed under the terms of the Creative Commons Attribution License, which permits unrestricted use, distribution, and reproduction in any medium, provided the original work is properly cited. 